\title{
Penilaian Risiko dengan Metode HIRADC Pada Pekerjaan Konstruksi Gedung Kebudayaan Sumatera Barat
}

\author{
Taufiq Ihsan $^{1 *}$, Sarah Azzahra Hamidi², Febyta Amanda Putri ${ }^{3}$ \\ 1,2,3 Jurusan Teknik Lingkungan, Fakultas Teknik, Universitas Andalas \\ *Correspondence email: taufiqihsan@eng.unand.ac.id
}

\begin{abstract}
Abstrak. Keselamatan dan Kesehatan Kerja sangat perlu menjadi pertimbangan bagi industri guna menghindari kecelakaan kerja. Pencegahan kecelakaan dapat dilakukan dengan menganalisis risiko yang ada, salah satunya adalah dengan metode HIRADC yaitu mengidentifikasi bahaya (Hazards Identification), menilai risiko (Risk Assessment) dan mengendalikan risiko (Determining Control). Penelitian ini bertujuan untuk melakukan penilaian risiko pada proyek Zona B Tahap II Gedung Kebudayaan Sumatera Barat. Sebagai kontraktor pengelola pada proyek tersebut, PT. X yang merupakan salah satu perusahaan di Sumatra Barat yang bergerak di bidang konstruksi, telah berusaha agar tidak terjadinya kasus kecelakaan kerja. Namun dalam pelaksanaan proyek ini tercatat 12 kecelakaan kerja pada masing-masing tiga jenis pekerjaan yaitu pembesian, bekisting, dan scaffolding. Hasil penilaian yang diperoleh pada proyek konstruksi Gedung Kebudayaan Sumatera Barat Zona B Tahap II ini memiliki risiko yang signifikan. Risiko signifikan perlu dipertimbangkan oleh manajemen kontraktor dan mengambil tindakan perbaikan. Perbaikan yang direkomendasikan adalah rekayasa, kontrol administratif, dan pemakaian Alat Pelindung Diri.
\end{abstract}

Kata kunci: Analisis Risiko; Bahaya Pekerjaan; HIRADC; Konstruksi

\begin{abstract}
Occupational Health and Safety really needs to be a consideration for industry in order to avoid work accidents. Accident prevention can be done by analyzing existing risks, one of which is the HIRADC method, namely identifying hazards (Hazards Identification), assessing risks (Risk Assessment) and controlling risks (Determining Control). This study aims to conduct a risk assessment in the Zone B Phase II project of the West Sumatra Cultural Building. As a managing contractor for the project, PT. X, which is a company in West Sumatra engaged in construction, has tried to prevent work accidents from occurring. However, in the implementation of this project, 12 work accidents were recorded for each of the three types of work, namely ironwork, formwork, and scaffolding. The results of the assessment obtained in the West Sumatra Zone B Phase II Cultural Building construction project have a significant risk. Significant risks need to be considered by contractor management and take corrective action. Recommended improvements are engineering, administrative controls, and use of Personal Protective Equipment.
\end{abstract}

Keywords: Risk Analysis; Occupational Hazard; HIRADC; Construction

\section{PENDAHULUAN}

Keselamatan dan kesehatan kerja (K3) adalah hal yang esensial, dimanapun berada temasuk pada lingkup pekerjaan di perusahaan. Dampak dari penyakit dan penyakit kerja akibat tidak mengindahkan K3, bukan hanya mencelakakan pekerja, namun juga menimbulkan kerugian baik secara langsung maupun tidak langsung terhadap perusahaan (Irzal, 2016). Pengertian tersebut menjurus pada interaksi pekerja dengan peralatan atau mesin yang dipakai, interaksi pekerja dengan lingkungan kerja, serta interaksi pekerja dengan kedua-duanya; mesin dan lingkungan kerja. K3 ini merujuk pada kondisi-kondisi fisiologis dan psikologis pekerja yang disebabkan oleh lingkungan kerja pada perusahaan (Wu, 2016).

Industri di bidang konstruksi adalah salah satu lingkungan kerja yang paling berbahaya dan rawan kecelakaan dan merupakan salah satu bisnis dengan risiko tertinggi sejauh menyangkut kegiatannya. Pekerja bangunan terpapar bahaya konstruksi yang dapat mengakibatkan cedera atau bahkan kematian. Mereka menghadapi berbagai jenis gangguan keamanan dan kesehatan saat bekerja di lokasi kerja mereka setiap hari (Andhini, 2015)

Berdasarkan catatan Bina Konstruksi Kementerian Pekerjaan Umum dan Penataan Ruang, pada tahun 2019 terdapat 130.923 kecelakaan kerja, dimana paling banyak di proyek konstruksi di Indonesia sehingga diperlukan upaya dalam menjamin K3. K3 pada bidang konstruksi merupakan penggalan dari sistem manajemen organisasi di bidang pekerjaan umum sebagai upaya pengendalian risiko K3 untuk segala sesuatu pekerjaan konstruksi. Tak terkecuali, kegiatan pengerjaan konstruksi Gedung Kebudayaan Sumatera Barat Zona B Tahap II, tentu termasuk dan memiliki potensi bahaya yang tinggi. PT. X sebagai kontraktor pelaksana berupaya memberikan kepedulian terhadap proyek pembangunan Gedung Kebudayaan Sumatera Barat Zona B Tahap II yang diwujudkan dengan penerapan standar keselamatan sebagai salah satu upaya dalam K3.

PT. X adalah perusahaan yang memberikan jasa bidang konstruksi di Provinsi Sumatra Barat. Perusahaan ini menjadi kontraktor pelaksana proyek pembangunan Gedung Kebudayaan Sumatera Barat Zona B Tahap II memiliki jumlah pekerja 110 orang dengan waktu pengerjaan proyek selama enam bulan. Menurut Pedoman Sistem Manajemen Keselamatan dan Kesehatan Kerja (SMK3) Kontruksi Bidang Pekerjaan Umum, yang tercantum pada Peraturan 
Menteri Pekerjaan Umum No. 5 Tahun 2014, bahwa proyek dengan potensi bahaya yang tinggi serta mempunyai jumlah pekerja > 100 orang, maka wajib menerapkan SMK3 (Prihatiningsih, 2014).

Pekerjaan yang memiliki tenaga kerja dengan jumlah yang besar dan banyak risiko kecelakaan kerja memerlukan suatu manajemen risiko yang dapat mengurangi potensi dari risiko kecelakaan tersebut. Berbagai ragam bahaya seperti fisik, kimia, elektrik, fisiologis, biologis, dan ergonomik dapat terjadi karena adanya ketidaksesuaian dengan pekerjaan yang dilakukan (Salami, 2016). Bahaya merupakan situasi maupun tindakan yang mempunyai potensi risiko untuk menghasilkan cidera, kerusakan ataupun kecelakaan pada manusia, serta gangguan lainnya (Jannah, 2017).

Risiko merupakan paparan dengan keparahan dari cidera atau gangguan kesehatan yang diakibatkan oleh paparan atau kejadian itu, ataupun kompilasi dari beragam kemungkinan terjadinya kejadian berbahaya. Sementara itu, penilaian risiko yaitu runtunan evaluasi risiko-risiko yang disebabkan oleh adanya bahaya dengan memperhatikan pemenuhan kebutuhan pengendalian yang tersedia dan menentukan risiko tersebut dapat ditolerir atau tidak. Oleh karenanya memerlukan manajemen risiko sebagai proses untuk mengendalikan risiko yang ada pada setiap usaha. Kemungkinan timbulnya suatu kejadian dan konsekuensi atau akibat yang dapat muncul akibat kejadian tersebu, menjadi suatu langkah dalam pengukuran risiko (Wu, 2019). Ini digambarkan dalam SMK3.

Penerapan OHSAS 18001 menjadi salah satu SMK3 yang sering dijumpai pada dunia industri serta pada beragam penelitian (Wu, 2019). Sesuai persyaratan di klausul 4.3.1 bahwa suatu usaha wajib menetapkan prosedur dan melakukan HIRADC yang merupakan singkatan dari Hazards Identification (identifikasi bahaya), Risk Assessment (penilaian risiko) dan Determining Control (pengendalian risiko). HIRADC menjadi elemen penting dalam SMK3 karena bersangkutan langsung dengan usaha preventif dan pengawasan bahaya yang digunakan untuk menentukan tujuan dan perencanaan K3 (Shamsuddin, 2015; Shamsuddin, 2015). Pemerintah Indonesia melalui Peraturan Pemerintah No. 50 Tahun 2012 tentang Penerapan SMK3 menyebutkan bahwa SMK3 wajib dilaksanakan oleh beberapa industri. Melalui Lampiran II point 2.1.2 dalam peraturan itu, menyatakan identifikasi potensi bahaya, penilaian dan pengendalian risiko K3 mesti diperhitungkan pada saat menetapkan rencana dan strategi K3 serta diperlukannya pengidentifikasian sumber bahaya, analisis dan pengendalian risiko oleh pelaksana yang berkompeten.

HIRADC haruslah mencakup hal-hal sebagai berikut (Sari, 2017): kegiatan rutin dan tidak rutin; kegiatan semua pekerja yang berkenaan dengan tempat kerja; kebiasaan dan kemampuan pekerja, serta human factors lainnya; bahaya yang muncul dari luar lingkungan tempat kerja yang dapat memberikan pengaruh buruk terhadap K3 pekerja; prasarana, peralatan dan material yang tersedia di tempat kerja, baik yang dsediakan oleh perusahaan maupun dari pihak luar; perubahan dan usulan perubahan dalam usaha, kegiatan atau material; perubahan dalam SMK3, termasuk perubahan sementara dan dampaknya terhadap proses, operasional dan aktivitas; beragam peraturan pemerintah yang berkaitan dengan prakiraan bahaya dan penerapan dari pengaturan yang diperlukan; rancangan dari area tempat proses kerja, perakitan mesin atau peralatan, pelaksanaan standar prosedur kerja perusahaan, termasuk adaptasi dari pekerja.

Untuk itu pada studi kasus ini, penting dilakukan pengidentifikasian bahaya, penilaian risiko, dan pengendalian risiko yang dapat dilaksanakan agar kecelakaan kerja yang terjadi bisa diminimalisir dan dapat memberikan informasi serta evaluasi bagi kegiatan sejenis untuk ke depannya.

\section{METODE}

Kegiatan konstruksi pada studi ini berlangsung selama enam bulan. Penelitian dilakukan pada area kerja di proyek Zona B Tahap II Gedung Kebudayaan Sumatera Barat pada Oktober - November 2019. Metode yang dipakai adalah observasi di lapangan serta melakukan metode HIRADC, yang mempunyai dari tiga tahapan yaitu Pengidentifikasian Bahaya, Penilaian Risiko serta Pengendalian Risiko:

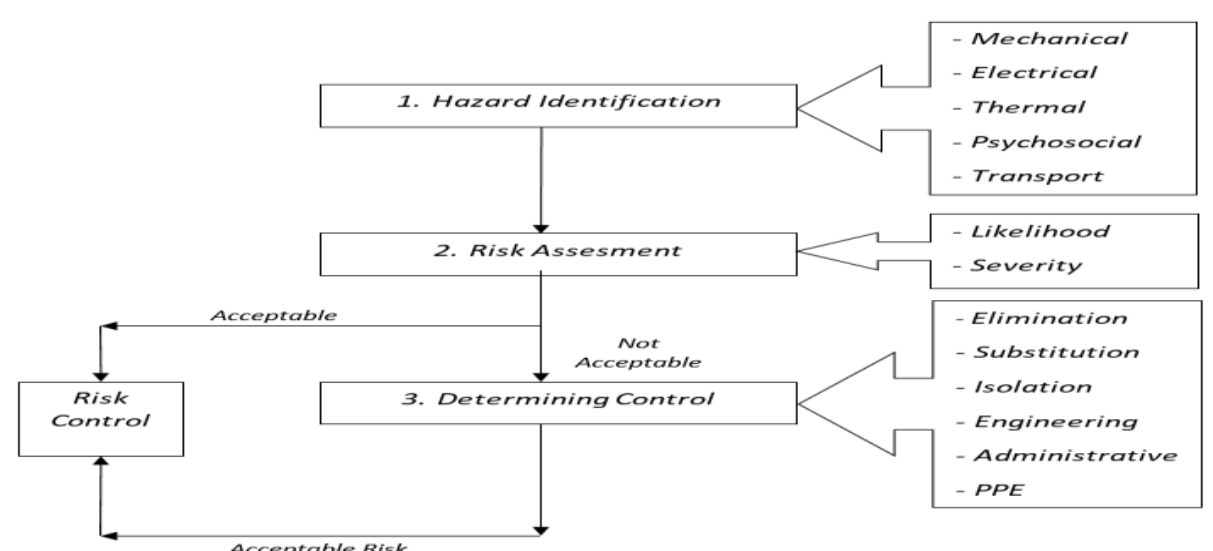

Gambar 1. Bagan Alir HIRADC 
Pengidentifikasian bahaya menjadi suatu proses yang bisa dilakukan guna mengenali semua kejadian atau situasi yang berpotensi sebagai penyebab kecelakaan dan penyakit akibat kerja yang mungkin timbul di tempat konstruksi. Identifikasi bahaya harus dilakukan secara benar dengan menggunakan pendekatan sistematis dan terstruktur, sehingga setiap risiko dapat teridentifikasi yang kemudian dianalisis lebih lanjut. Langkah awal dalam identifikasi adalah menetapkan pembagian identifikasi bahaya berdasarkan area atau proses kerja. Setiap proses yang ada, dilakukan identifikasi bahaya yang terjadi berdasar pada berbagai unsur bahaya. Identifikasi menurut unsur bahaya ini dilakukan dengan melihat kepada area kerja, peralatan atau mesin yang dipakai, kebiasaan dan tindakan operator bekerja serta material yang dipakai (Rout, 2017).

Risiko (risk) memperlihatkan kemungkinan munculnya suatu kecelakaan pada siklus operasi atau periode waktu tertentu. Penilaian risiko merupakan proses penilaian dari kegiatan-kegiatan yang telah dilakukan pengidentifikasian bahaya sebelumnya. Penilaian risiko berarti memberikan nilai terhadap tingkat keparahan dampak yang ditimbulkan (severity) dan peryebab potensi bahaya tersebut seberapa seringnya terjadi (likelihood). Dalam penetapan nilai-nilai yang sama dan tepat untuk semua proses kerja, dibuat suatu definisi tentang skala yang telah ditetapkan (Tarwaka, 2014). Definisi skala untuk severity dilakukan berdasarkan keparahan secara fisik dan materi, sedangkan definisi skala penilaian likelihood dilakukan berdasarkan berapa kali kondisi penyebab bahaya terjadi dan suatu kegiatan penyebab bahaya dikerjakan.

Dalam konteks proyek konstruksi, risiko adalah peristiwa yang, jika terjadi, berdampak buruk terhadap pencapaian tujuan proyek (Suárez-Sánchez, 2017). Risiko pengukuran untuk mengevaluasi bahaya. Menentukan nilai risiko bahaya konstruksi tergantung pada likelihood dan severity-nya dengan rumus:

Risk $(\mathrm{R})=$ Likelihood $(\mathrm{L}) \times$ Severity $(\mathrm{S})$

Manajemen risiko merupakan proses yang selalu diterapkan pada seluruh aspek operasi bisnis. Implementasi manajemen risiko terdapat tujuh langkah yang harus dilaksanakan yaitu: mengkomunikasikan dan konsultasi; memutuskan konteks; mengidentifikasi risiko; menganalisis risiko; mengevaluasi risiko; perlakuan risiko, memantau; serta menelaahnya. Dalam menilai maupun menganalisis suatu risiko dengan metode perbandingan terhadap suatu gambaran/ uraian dari parameter peluang dan akibat yang dipakai, adalah penilaian risiko secara kualitatif. Tabel 1 dan 2 berikut menjabarkan sistem penilaian yang ada pada Australia Standard/ New Zealand Standard No 4360 (AS/NZS 4360):

Tabel 1. Metode Penilaian Risiko Berdasarkan Likelihood

\begin{tabular}{|c|c|c|}
\hline Tingkat & Kategori & Uraian \\
\hline A & Almost certain & $\begin{array}{l}\text { Suatu kasus yang pasti muncul di setiap keadaan/ semua kegiatan yang dilaksanakan } \\
\text { oleh industri/usaha. }\end{array}$ \\
\hline $\mathrm{B}$ & Likely & Suatu kasus yang mungkin akan muncul pada hampir setiap keadaan. \\
\hline $\mathrm{C}$ & Moderate & Suatu kasus yang akan muncul dalam beberapa keadaan tertentu. \\
\hline $\mathrm{D}$ & Unlikely & $\begin{array}{l}\text { Suatu kasus yang kecil kemungkinannya untuk muncul pada beberapa keadaan } \\
\text { tertentu. }\end{array}$ \\
\hline $\mathrm{E}$ & Rare & $\begin{array}{l}\text { Suatu kasus yang mungkin muncul pada suatu keadaan yang luar biasa/ khusus/ } \\
\text { setelah bertahun-tahun tidak terjadi. }\end{array}$ \\
\hline
\end{tabular}

Sumber: Purohit, 2018

Tabel 2. Metode Penilaian Risiko Berdasarkan Severity

\begin{tabular}{cll}
\hline Tingkat & \multicolumn{1}{c}{ Kategori } & \multicolumn{1}{c}{ Uraian } \\
\hline 1 & Insignificant & Tanpa cidera dan/atau sangat kecil kerugian materinya. \\
2 & Minor & $\begin{array}{l}\text { Membutuhkan perawatan/ pertolongan pertama dan/atau tingkat kerugian materi } \\
\text { sedang. } \\
\text { Membutuhkan perawatan medis (sehingga membutuhkan istirahat sementara waktu) } \\
\text { yang berdampak pada hilangnya hari kerja dan dan/atau menimbulkan kerugian }\end{array}$ \\
& Moderate & $\begin{array}{l}\text { materi yang cukup besar. } \\
\text { Mengakibatkan kehilangan fungsi tubuh (cacat) dan/atau proses produksi terhenti } \\
\text { dan/atau mengakibatkan, kerugian materi yang besar. } \\
\text { Menyebabkan kematian dan/atau mengakibatkan kerugian materi yang sangat besar. }\end{array}$ \\
\end{tabular}

Sumber: Purohit, 2018

Matriks risiko nantinya dipakai sebagai dasar penilaian risiko. Kombinasi kemungkinan dan konsekuensi atau kisaran keparahan yang memberikan perkiraan risiko atau tingkat risiko merupakan matriks risiko. Tingkat matriks risiko pada pekerjaan konstruksi dimulai dengan menetapkan bagaimana matriks dimaksudkan untuk digunakan (Ahmad, 2016). Keputusan awal yang harus dibuat adalah untuk menentukan kriteria penerimaan atau toleransi risiko untuk organisasi menggunakan matriks (Ihsan, 2016). Matriks penilaian ini dapat dilihat pada Tabel 3 berikut. 
Tabel 3. Penilaian Risiko

\begin{tabular}{|c|c|c|c|c|c|}
\hline \multirow{2}{*}{ Kemungkinan } & \multicolumn{5}{|c|}{ Tingkat Risiko } \\
\hline & 1 & 2 & 3 & 4 & 5 \\
\hline $\mathrm{A}$ & $\mathrm{S}$ & $S$ & $\mathrm{~T}$ & $\mathrm{~T}$ & $\mathrm{~T}$ \\
\hline B & M & $\mathrm{S}$ & S & $\mathrm{T}$ & $\mathrm{T}$ \\
\hline $\mathrm{C}$ & $\mathrm{R}$ & M & $\mathrm{S}$ & $\mathrm{T}$ & $\mathrm{T}$ \\
\hline $\mathrm{D}$ & $\mathrm{R}$ & $\mathrm{R}$ & M & S & $\mathrm{T}$ \\
\hline $\mathrm{E}$ & $\mathrm{R}$ & $\mathrm{R}$ & M & S & $\mathrm{S}$ \\
\hline
\end{tabular}

Sumber: Prihatiningsih, 2014

\section{Keterangan:}

$\mathrm{T} \quad$ : Tinggi, kondisi darurat sehingga membutuhkan penanganan sesegera mungkin dan perubahan dan rancangan khusus pada manajemen tertinggimemerlukan perencanaan khusus di tingkat manajemen senior.

S : Signifikan, memerlukan perubahan dan perbaikan selekas mungkin serta membutuhkan perhatian dari pihak manajemen

M : Moderat, perlu lekas dilakukan tindakan penanganan namun bukan dalam keadaan yang darurat dan tidak memerlukan perhatian khusus dari manajemen.

$\mathrm{R} \quad$ : Rendah, risiko dapat ditangani dengan rutinitas standar operasi maupun prosedur yang berlaku.

Penilaian risiko maka bermakna pada keseluruhan proses analisis (identifikasi dan estimasi) juga evaluasi risiko (pengukuran dan toleransi) (Hola, 2014; Saeed, 2017). Dengan kata lain, penilaian risiko dapat didefinisikan semacam proses penilaian risiko yang berkenaan terhadap setiap bahaya konstruksi yang diidentifikasi. Penilaian bisa dilakukan dalam diskusi terstruktur, konsultasi atau pertemuan formal. Penilaian risiko mengandung informasi bahaya yang diidentifikasi yang dapat ditinjau atau diperbarui secara berkala ketika pekerjaan konstruksi berlangsung (Rubio-Romero, 2013). Selain itu, penilaian risiko perlu dilakukan secara sistematis agar penanggung jawab lokasi konstruksi yaitu manajer proyek dan petugas keselamatan dapat menyelesaikan apakah mereka telah mengambil tindakan pencegahan yang memadai atau harus melakukan langkah-langkah kontrol lebih banyak untuk mencegah bahaya (Al-Ajmi, 2018).

Tindakan pengendalian risiko dapat dimulai untuk memastikan keselamatan pekerja konstruksi dan tempat kerja, mengacu pada identifikasi bahaya dan penilaian risiko yang dilaksanakan pada tahap awal. Pengendalian risiko adalah penghapusan atau inaktivasi bahaya dengan cara sebegitu rupa sehingga tidak menimbulkan risiko bagi pekerja yang berada atau masuk ke suatu area kerja atau bekerja dengan peralatan yang telah ditetapkan. Pengendalian risiko menyiratkan dalam pengambilan langkah untuk membuang bahaya secara bijaksana yang akan menghilangkan atau mengurangi bahaya serta mengeluarkan bahaya yang terkait dengan bahaya (Albert, 2014).

Upaya pengendalian risiko berperan untuk mengontrol potensi risiko yang muncul sehingga bahaya tersebut sanggapu untuk dihilangkan atau diminimalisir hingga ambang batas yang diterima. Pengendalian risiko haruslah mengacu pada Pendekatan Hirarki Pengendalian (Hirarchy of Control). Hirarki ini menjadi acuan tahapan dang langkah-langkah dalam mencegah dan mengendalikan risiko yang ada dan akan timbul. Secara berurutan, tingkatannya yaitu Eliminasi (Elimination), Substitusi (Substitution), Rekayasa (Engineering), Administrasi (Administrative), dan Alat Pelindung Diri (APD/PPE) (Tarwaka, 2014). Seperti terlihat pada Gambar 2 berikut.

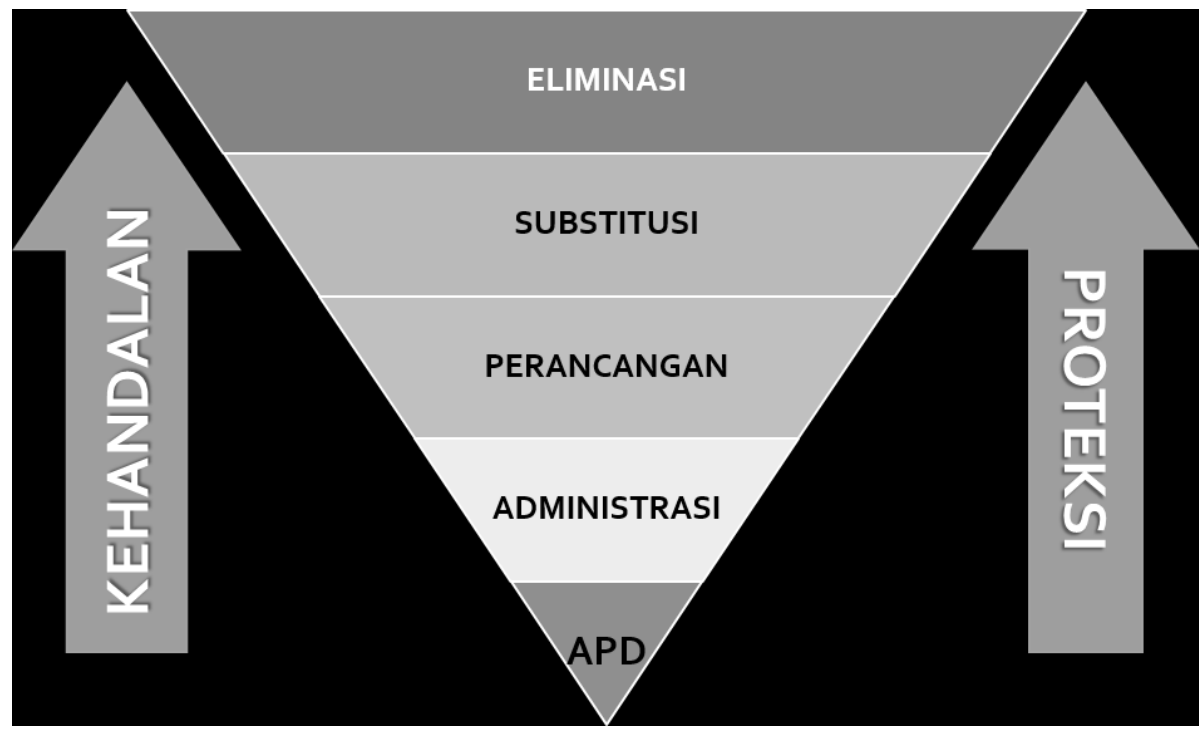

Gambar 2. Pengendalian Risiko Bahaya 
Hirarki pengendalian risiko, diawali oleh (Tarwaka, 2014) (1) Eliminasi: Pengendalian dengan meniadakan sehingga dampak tereduksi hingga sumber bahaya menjadi nol; (2) Subtitusi: Pengendalian dengan mengganti bahan, alat, sistem atau prosedur yang berbahaya dengan yang lebih rendah tingkat bahayanya atau lebih aman; (3) Engineering: Memodifikasi desain untuk meniadakan bahaya, misalnya mengubah sistem ventilasi, menyediakan perlindungan pada mesin, dan mengurangi sumber kebisingan; (4) Administratif: Menciptakan beberapa sistem terkait tata laksana dan prosedur guna memastikan pekerjaan yang aman, seperti pemasangan tanda keselamatan, membuat kerja gilir/ jadwal kerja, standar operasional dan prosedur kerja yang aman, pemeriksaan dan perawatan alat, dan pengecekan kesehatan berkala; (5) Alat Pelindung Diri: menggunakan alat pelindung diri merupakan pilihan terakhir dalam pengendalian risiko bahaya misalnya pelindung kepala, pelindung wajah, pelindung tangan, pelindung pendengaran, pelindung tubuh, pelindung tangan dan kaki, dan sebagainya.

\section{HASIL DAN PEMBAHASAN}

Berdasarkan Tabel 4 menunjukkan telah terjadi 12 kecelakaan kerja pada tiga jenis pekerjaan konstruksi yaitu pekerjaan pembesian, bekisting, dan scaffolding. Jumlah kejadian ini menunjukkan bahwa penerapan SMK3 belum optimal dalam pelaksanaan proyek ini. Meskipun Proyek Pembangunan Gedung Kebudayaan Sumatera Barat Zona B Tahap II oleh PT. Rimbo Peraduan ini telah memenuhi 45 kriteria dari 64 kriteria $(70,31 \%)$ untuk tingkatan awal yang berarti termasuk dalam tingkat penilaian penerapan baik;

Tabel 4. Data Kecelakaan Kerja

\begin{tabular}{|c|c|c|}
\hline No. & Aktivitas & Total Kejadian \\
\hline 1 & Pembesian & 2 \\
\hline 2 & Bekisting & 6 \\
\hline 3 & Scaffolding & 4 \\
\hline & Total & 12 \\
\hline
\end{tabular}

Uraian kejadian kecelakaan kerja pada Tabel 4 adalah sebagai berikut: (1) Pada kegiatan pembesian, saat menggunakan alat bar-bending, pekerja tidak sengaja menyentuh tombol power pada alat sehingga alat menyala dan jari tangan kanan pekerja terjepit pada alat; (2) Pada saat pembuatan (pabrikasi bekisting) tiba-tiba serpihan besi masuk ke mata pekerja. Berikutnya ada juga pekerja tertimpa balok kayu yang jatuh dari lantai 2. Balok kayu tersebut mengenai punggung dan lengan kiri sehingga bagian punggung luka memar atau lecet dan jari tangan kiri membengkak. Selain itu pada saat pembongkaran bekisting, ada juga kasus pekerja menggunakan linggis sebagai alat kerja. Linggis tersebut lepas dari pegangan dan terlempar mengenai dahi pekerja; (3) Saat turun dari scaffolding, pekerja menginjak kayu yang masih tertancap, paku tersebut menusuk telapak kaki pekerja kurang lebih sedalam $1 \mathrm{~cm}$. Selanjutnya ada kasus pekerja yang sedang melakukan pembongkaran scaffolding, besi scaffolding tejatuh dan menimpa kaki kiri pekerja sehingga tulang ibu jari dan telunjuk patah.

Tujuan suatu analisis adalah dengan pengelompokkan risiko kecil yang dapat diterima dari risiko berkategori besar; pengadaan data guna mengevaluasi; dan perlakuan risiko. Analisis risiko melingkupi pertimbangan mengenai sumber risiko, severity dan likelihood munculnya konsekuensi. Kombinasi estimasi terhadap konsekuensi dan likelihood di dalam konteks tindakan pengendalian yang ada, membantu untuk menganalisis risiko (Landage, 2016).

Hasil identifikasi bahaya, pengendalian risiko, dan pengendalian yang telah dilakukan perusahaan serta saran tambahan pengendalian risiko ada pada Tabel 5.

Tabel 5. HIRADC pada Proyek Pembangunan Gedung Kebudayaan Sumatera Barat Zona B Tahap II

\begin{tabular}{|c|c|c|c|c|c|c|c|c|c|}
\hline \multirow[b]{2}{*}{ No } & \multirow[b]{2}{*}{ Aktivitas } & \multirow[b]{2}{*}{ Bahaya } & \multirow[b]{2}{*}{ Konsekuensi } & \multirow{2}{*}{$\begin{array}{l}\text { Tindakan } \\
\text { Pengendalian } \\
\text { Eksisting }\end{array}$} & \multicolumn{3}{|c|}{ Rating Risiko } & \multirow{2}{*}{$\begin{array}{c}\text { Penanggung } \\
\text { Jawab }\end{array}$} & \multirow{2}{*}{$\begin{array}{l}\text { Target } \\
\text { Waktu }\end{array}$} \\
\hline & & & & & $\mathrm{P}^{*}$ & $\mathrm{C}^{* *}$ & $\mathrm{R}^{* * * *}$ & & \\
\hline 1 & Pembesian & $\begin{array}{l}\text { Alat kerja tidak } \\
\text { berfungsi } \\
\text { sebagaimana } \\
\text { mestinya }\end{array}$ & $\begin{array}{l}\text { Cedera } \\
\text { terjepit dan } \\
\text { tergores; }\end{array}$ & $\begin{array}{l}\text { - Penyediaan APD } \\
\text { (pelindung } \\
\text { tangan, sepatu } \\
\text { pelindung, helm } \\
\text { pelindung, safety } \\
\text { belt dan body } \\
\text { harnes, welding } \\
\text { helmets); } \\
\text { - Pengawasan } \\
\text { APD }\end{array}$ & $\mathrm{C}$ & 3 & S & Kontraktor & $\begin{array}{c}1 \\
\text { minggu }\end{array}$ \\
\hline
\end{tabular}




\begin{tabular}{|c|c|c|c|c|c|c|c|c|c|}
\hline 2 & Bekisting & $\begin{array}{l}\text {-Pabrikasi } \\
\text { bekisting } \\
\text {-Bahaya } \\
\text { kejatuhan } \\
\text { bahan dari } \\
\text { ke-tinggian } \\
\text {-Pembongkaran } \\
\text { bekisting }\end{array}$ & $\begin{array}{l}\text {-Mata } \\
\text { terkena } \\
\text { percikan; } \\
\text {-Tertimpa } \\
\text { balok kayu; } \\
\text {-Cedera } \\
\text { kejatuhan } \\
\text { alat. }\end{array}$ & $\begin{array}{l}\text { - Penyediaan APD } \\
\text { (pelindung } \\
\text { tangan, sepatu } \\
\text { pelindung, helm } \\
\text { pelindung, } \\
\text { masker); } \\
\text { - Pemantauan } \\
\text { penerapan dan } \\
\text { penggunaan } \\
\text { APD }\end{array}$ & B & 2 & S & Kontraktor & $\begin{array}{c}1 \\
\text { minggu }\end{array}$ \\
\hline 3 & Scaffolding & $\begin{array}{l}\text {-Bahaya sisa } \\
\text { bahan } \\
- \\
\text { Pembongkara } \\
\text { n scaffloding }\end{array}$ & $\begin{array}{l}\text {-Telapak } \\
\text { kaki } \\
\text { tertusuk } \\
\text { material } \\
\text { tajam; } \\
\text {-Tertimpa } \\
\text { besi yang } \\
\text { terjatuh. }\end{array}$ & $\begin{array}{l}\text { - Penyediaan APD } \\
\text { (spelindung } \\
\text { tangan, sepatu } \\
\text { pelindung, helm } \\
\text { pelindung, } \\
\text { masker dan } \\
\text { kacamata); } \\
\text { - Pemantauan } \\
\text { penerapan dan } \\
\text { penggunaan } \\
\text { APD serta } \\
\text { lingkungan kerja }\end{array}$ & B & 2 & S & Kontraktor & $\begin{array}{c}1 \\
\text { minggu }\end{array}$ \\
\hline
\end{tabular}

\section{Keterangan:}

* Probability (Peluang) nilai mengacu pada Tabel 1

** Consuquency (Akibat) nilai mengacu pada Tabel 2

*** Risk (Risiko) nilai mengacu pada Tabel 3

Pada Tabel 5, memperlihatkan kecelakaan kerja pada pekerjaan pembesian untuk memiliki peluang "sedang" dengan akibat "sedang" dan risiko yang signifikan. Sementara itu untuk bekisting dan scaffolding, memiliki peluang kejadian kecelakaan kerja "mungkin terjadi" dengan akibat rendah dan risiko yang signifikan. Sehingga dapat ditarik kesimpulan, risiko keseluruhan untuk kecelakaan kerja pada proyek ini adlaah signifikan.

Berdasarkan analisis tersebut, maka dapat dilakukan tambahan tindakan pengendalian sebagai berikut (Cakmak, 2019):

1. Pembesian, membutuhkan tindakan perbaikan dan kepedulian dari pihak manajemen dan serta melakukannya selekas mungkin yaitu:

a. Melakukan perbaikan pada alat;

b. Penekanan sikap berhati-hati pada pekerja oleh pengawas lapangan saat pertemuan awal sebelum memulai pekerjaan. Ini dilakukan setiap hari kerja;

c. Pengawasan saat bekerja secara teratur dan disiplin oleh pelaksana K3 setiap hari kerjanya.

2. Bekisting, membutuhkan tindakan perbaikan dan kepedulian dari pihak manajemen dan serta melakukannya selekas mungkin yaitu:

a. Penggunaan APD yang sesuai dengan karakteristik kerja yang telah ditentukan;

b. Pengawasan saat bekerja secara teratur dan disiplin oleh pelaksana K3 setiap hari kerjanya;

c. Memindahkan perletakan bahan kayu di tempat yang aman dan tidak berserakan (tidak teratur)

d. Bekerja pada jarak yang aman;

d. Penekanan sikap berhati-hati pada pekerja oleh pengawas lapangan saat pertemuan awal sebelum memulai pekerjaan. Ini dilakukan setiap hari kerja;

3. Scaffolding, membutuhkan tindakan perbaikan dan kepedulian dari pihak manajemen dan serta melakukannya selekas mungkin yaitu:

a. Melakukan pembersihan sisa material yang sudah dipakai dan menempatkannya pada titik kumpul aman yang sudah ditetapkan serta tidak berserakan (tidak teratur);

b. Pengawasan saat bekerja secara teratur dan disiplin oleh pelaksana K3 setiap hari kerjanya;

c. Penekanan sikap berhati-hati pada saat pertemuan sebelum memulai pekerjaan setiap harinya;

d. Bekerja pada jarak yang aman.

Pada setiap aktivitas pekerjaan, sangat perlu bagi pengawas proyek dalam merancang pembagian waktu istirahat, melaksanakan perenggangan pada rentang waktu tertentu setelah bekerja, memperkaya pengetahuan terkait bahaya ergonomi di lingkungan kerja. Hal ini sesuai dengan penelitian Aerrosa (2020). Dengan demikian, untuk memastikan keselamatan pekerja, program pemeliharaan dan pengawasan harus dimasukkan dalam rencana 
manajemen K3. Ini harus mencakup jadwal untuk peningkatan esensial serta pembaruan peralatan dalam kegiatan konstruksi. Ini penting untuk efisiensi biaya, keamanan serta untuk menghindari kerusakan dan kerusakan material (Ihsan, 2020). Selain itu guna memastikan bahwa program keselamatan yang berhasil dilaksanakan di lokasi, kondisi berikut harus dibuat (Sharma, 2015): (1) Komitmen Manajemen; ini termasuk kepemimpinan, visi, dan arah, pernyataan tujuan, komitmen, pengawasan, analisis keselamatan, dan perencanaan pencegahan; (2) Kondisi Kerja yang Aman; ini termasuk tata graha yang tepat, tata letak situs yang tepat, dan ketersediaan ruang; (3) Kebiasaan Kerja yang Aman; ini termasuk kesadaran, komunikasi yang baik, sikap pribadi, budaya keselamatan, kelompok positif dan kompetensi pribadi.

Dengan kata lain, program keselamatan yang berhasil didasarkan pada komitmen dan partisipasi manajemen dan pekerja dalam pembuatan kebijakan dan dalam membangun sistem umpan balik yang memadai yang akan mengarah pada peningkatan berkesinambungan dari program keselamatan.

Pada akhirnya, tujuan atau intinya dengan laporan bahaya HIRADC ini adalah untuk mencapai tujuan Zero Accident atau Zero Lost of the Time Injury Accident. Dengan memiliki sistem kerja yang aman, maka akan mencegah terjadinya kecelakaan dimana pencegahan kecelakaan memang merupakan masalah yang berbiaya efektif. Selain itu, pemerintah perlu menegakkan hukum K3 terutama terkait konstruksi untuk memastikan semua kegiatan telah mengikuti pedoman budaya kerja yang aman. Dari waktu ke waktu, pemerintah juga perlu melakukan beberapa kampanye atau lokakarya untuk meningkatkan kesadaran masyarakat tentang budaya kerja yang aman dan perlunya mengikuti peraturan. Pekerja harus tetap waspada dan sadar setiap saat untuk menghindari kecelakaan, sementara pengelola proyek konstruksi perlu mengetahui penyebab paling umum untuk kecelakaan di tempat kerja dan dapat mengenali faktor risiko lebih awal untuk pencegahan (Yakubu, 2013).

\section{SIMPULAN}

Pada proyek pembangunan Gedung Kebudayaan Sumatera Barat Zona B Tahap II menunjukkan telah terjadi 12 kecelakaan kerja pada tiga jenis pekerjaan konstruksi yaitu pekerjaan pembesian, bekisting dan scaffolding. Dari data kecelakaan kerja tersebut dilakukan análisis risiko K3 menggunakan metode HIRADC, didapatkan kesimpulan bahwa pekerjaan konstruksi pada pembangunan Proyek Gedung Kebudayaan Sumatera Barat Zona B Tahap II memiliki risiko yang signifikan. Risiko yang signifikan perlu dilaksanakan tindakan perbaikan dan kepedulian dari pihak manajemen dan serta melakukan perubahan selekas mungkin.

Analisis risiko K3 dari data kecelakaan kerja tersebut dapat diuraikan menjadi pekerjaan pembesian untuk kecelakaan kerjanya mempunyai peluang sedang dengan akibat sedang dan risiko yang signifikan, pekerjaan bekisting mempunyai peluang mungkin terjadi dengan akibat rendah dan risiko yang signifikan, selanjutnya yang terakhir pekerjaan scaffolding mempunyai peluang mungkin terjadi dengan akibat rendah dan risiko yang signifikan.

\section{DAFTAR PUSTAKA}

Aerrosa, M, M. 2020. Penggunaan HIRARC dalam Identifikasi Bahaya dan Penilaian Risiko pada Pekerjaan Bongkar Muat. HIGEIA (Journal of Public Health Research and Development), 4 (2): 245-255.

Ahmad, C. A, Zin, I. N. M., Wahid, A. M. A., \& Kamar, I. F. M. 2016. Hazard and risk of highway maintenance: case study of PLUS Expressways. In The 4th International Building Control Conference 2016, MATEC Web of Conferences, 66 (106), 1-7.

Al-Ajmi, H. F., \& Makinde, E. 2018. Risk Management in Construction Projects. Journal of Advanced Management Science, 6 (2): 113-116.

Albert, A., Hallowell, M. R., \& Kleiner, B. M. 2014. Emerging strategies for construction safety \& health hazard recognition. Journal of Safety, Health \& Environment Research, 10 (2): 152-161.

Andhini, D.P., Sugiono., \& Remba, Y.E. 2015. Implementation of Job Safety Analysis (JSA) in Prevention Work Accident (Case Study: PT. Adi Putro Wirasejati). Jurnal Rekayasa dan Manajemen Sistem Industri, 3(2): 386-396.

Cakmak, P. I., \& Tezel, E. 2019. Risk Management in Construction Projects, Nthatisi Khatleli, IntechOpen, DOI: 10.5772/intechopen.84361.

https://www.intechopen.com/books/risk-management-in-construction-projects/a-guide-for-risk-management-inconstruction-projects-present-knowledge-and-future-directions

Hola, B., \& Szóstak, M. 2014. Analysis of the Development of Accident Situations in the Construction Industry. Procedia Eng, 91:429-434.

Ihsan, T., Edwin, T., \& Octavianus R. I. 2016. Analisis Risiko K3 dengan Metode HIRARC pada Area Produksi PT Cahaya Murni Andalas Permai. Jurnal Kesehatan Masyarakat Andalas, 10(2): 179-185.

Ihsan, T., Safitri, A., \& Dharossa, D. P. 2020. Analisis Risiko Potensi Bahaya dan Pengendaliannya dengan Metode HIRADC pada PT. IGASAR Kota Padang Sumatera Barat. Jurnal Serambi Engineering, 5 (2): 1063-1069.

Irzal. 2016. Dasar-Dasar Kesehatan dan Keselamatan Kerja: Edisi 1. Jakarta: Penerbit Kencana. 
Jannah, M.R., Unas, S.E., \& Hasyim, M.H. 2017. Analisis risiko Keselamatan dan Kesehatan Kerja (K3) melalui pendekatan HIRADC dan metode job safety analysis pada studi kasus proyek pembangunan menara x di jakarta. Jurnal Mahasiswa Jurusan Teknik Sipil. 1(2): 1-8.

Landage, A. 2016. Risk Management in Construction Industry. International Journal of Engineering Research, 5:153-155. 10.17950/ijer/v5i1/035.

Prihatiningsih, S., \& Suwandi, T. 2014. Penerapan Metode HIRADC Sebagai Upaya Pencegahan Kecelakaan Kerja Pada Pekerja Mesin Rewinder. The Indonesian Journal of Occupational Safety, Health and Environment, 1(1): 73-84

Purohit, D. P., Siddiqui, N. A., Nandan, A., \& Yadav, B. P. 2018. Hazard Identification and Risk Assessment in Construction Industry. International Journal of Applied Engineering Research 13(10): 7639-7667.

Rout, B. K., \& Sikdar, B. K. 2017. Hazard Identification, Risk Assessment, and Control Measures as an Effective Tool of Occupational Health Assessment of Hazardous Process in an Iron Ore Pelletizing Industry.Indian $J$ Occup Environ Med, 21(2): 56-76.

Rubio-Romero, J., G'amez, C. R., \& Carrillo-Castrillo, J. 2013. Analysis of the safety conditions of scaffolding on construction sites. Safety Science, 55:160--164.

Saeed, Y. 2017. Safety Management in Construction Projects. The Journal of The University of Duhok, 20:546-560.

Salami, I. R. S. 2016. Kesehatan dan keselamatan lingkungan kerja. Cetakan kedua. Yogyakarta: UGM Press.

Sari, R. M., Syahputri, K., Rizkya, I., \& Siregar, I. 2017. Identification of Potential Hazard using Hazard Identification and Risk Assessment. IOP Conference Series: Materials Science and Engineering, 180(1). doi. https://doi.org/10.1088/1757-899X/180/1/01212

Shamsuddin, K. A., Ani, M. N. C., Ismail, A. K., \& Ibrahim, M. R. 2015. Investigation the Safety, Health and Environment (SHE) protection in construction area. International Research Journal of Engineering and Technology, 2(6):624-636.

Shamsuddin, K.A., Norzaimi, C.M., Che-Ani, A.I., \& Ismail, A.K. 2015. Investigation the effective of the Hazard Identification, Risk Assessment and Determining Control (HIRADC) in manufacturing process. International Journal of Innovative Research in Advanced Engineering (IJIRAE), 2(8): 80-84.

Sharma, A., Kumar, A., \& Suryawanshi, V. 2015. Hazard Identification and Evalution in Construction Industry. International Journal of Science Technology \& Engineering, 1(10):47-56

Suárez-Sánchez, F. A., Carvajal-Peláez, G. I., \& Catalá-Alís, J. 2017. Occupational safety and health in construction: a review of applications and trends. Industrial health, 55(3):210-218.

Tarwaka. 2014. Keselamatan dan Kesehatan Kerja (K3): Manajemen dan Implementasi K3 di Tempat Kerja. Edisi II. Surakarta: Harapan Press.

Wu, P., \& Wang, X. 2019. Innovative Production and Construction: Transforming Construction Through Emerging Technologies.Singapore: World Scientific Publishing.

Yakubu, D. M., \& Bakri, I. M. 2013. Evaluation of Safety and Health Performance on Construction Sites (Kuala Lumpur). Journal of Management and Sustainability, 3(2). doi:10.5539/jms.v3n2p100.

Zin, S., \& Ismail, F. 2012. Employers' behavioural safety compliance factors toward occupational, safety and health improvement in the construction industry. Procedia-Social and Behavioral Sciences, 36:742-751. 